\title{
Nutritional contents of processed Delonix regia seeds incubated in vitro with
} Pennisetum purpureum

${ }^{1}$ Olufayo, O. O. and ${ }^{2}$ Falola, O. O.

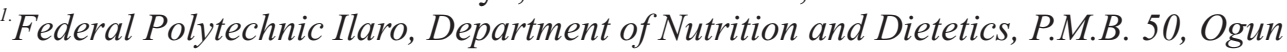
State, Nigeria.

${ }^{2}$ Federal College of Animal Production and Health Technology, Moor Plantation, Ibadan, Nigeria.

Corresponding author: mobo4sola@yahoo.com,+2348056246950.

\section{Abstract}

The effect of processing on proximate, mineral, anti-nutritional compositions, gas production characteristics, methane production, predicted metabolizable energy, organic matter digestibility and short chain fatty acids production of Delonix regia seeds incubated with Pennisetum purpureum were determined. Five treatments (T1: mixture of soaked Delonix regia seed and Pennisetum purpureum; T2: mixture of raw Delonix regia seed and Pennisetum purpureum; T3: mixture of roasted Delonix regia seed and Pennisetum purpureum; T4: mixture of boiled Delonix regia seed and Pennisetum purpureum and T5:100\% Pennisetum purpureum which serves as control) were designed. In vitro gas production techniques for 24 hours were used to determine the nutritive value of processed $50 \%$ Delonix regia seed and 50\% Pennisetum purpureum. The crude protein ranged from 13.38 to $15.71 \mathrm{~g} / 100 \mathrm{~g}$ DM among the treatments while crude fibre was between 20.10 and $21.40 \mathrm{~g} / 100 \mathrm{~g} \mathrm{DM}$, ether extract ranged from 1.90 to $3.12 \mathrm{~g} / 100 \mathrm{~g} \mathrm{DM}$ and ash 7.77 to $12.34 \mathrm{~g} / 100 \mathrm{~g}$ DM. Calcium ranged from (2.34 - 3.61\%), magnesium ranged $(2.90-3.48 \%)$, sodium $(2.05-2.91 \%)$ and phosphorus $(0.88-1.12 \%)$. It was observed generally that T2 recorded the highest among the treatments while the values obtained for the heat treated seeds were lower than the raw. Oxalates ranged between $(0.23 \%-0.32 \%)$, phytates $(0.29-0.43 \%)$, tannin $(0.03-0.08 \%)$ and saponnin $(0.36-0.49 \%)$. Methane $(\mathrm{ml} / 200 \mathrm{mg} \mathrm{DM})$ production indicated T3 (50\% roasted Delonix regia seed and 50\% Pennisetum purpureum) was highest. The potential gas production ' $a+b$ ' ranged from 12.33 to $28.33 \mathrm{~mL} / 200 \mathrm{mg} D \mathrm{DM}$ ). The highest potential gas production ' $a+b$ ' value of $28.33 \mathrm{~mL} / 200 \mathrm{mg}$ DMwas obtained in T1 compared to other dietary treatment. Dry matter digestibility (DMD) ranged between 70.23 $91.02 \%$ while the rate of fermentation was between 0.51 and $1.18 \mathrm{ml} / \mathrm{hr}$. The rate of fermentation was directly proportional to dry matter digestibility (DMD); the soaked recorded the highest value. Processing enhanced the nutritional contents of Delonix regia seeds. The result obtained showed that there were significant differences $(p<0.05)$ among the treatments. In conclusion, soaking the seeds of Delonix regia had beter nutritional contents and has the potential for dry season feeding.

Keywords: Processing, Nutritional Contents, Delonix regia seeds, Pennisetum purpureum

\section{Introduction}

The conventional protein feedstuffs for livestock are scarce and not readily available, because the feedstuffs are competed for by animals and humans. These feedstuffs could be substituted by seeds of multipurpose trees that are high in crude protein. Ruminants are good at converting grasses, legumes and browse plants that are totally inedible to man, to flesh. Limited and inadequate supply of forage with low quality feed in dry season eventually results in retarded growth of animals and reduction in milk and meat production (Babayemi et al., 2004). Feeding animals with grass/ legumes mixtures have 


\section{Processed Delonix regia seeds incubated in vitro with Pennisetum purpureum}

been reported to give better animal performance and productivity than feeding grasses or legumes alone because the nutrient intake is balanced. Producing and properly preserving high quality grasses and legumes can reduce the costs, thereby making feed readily available and improving productivity (Schroeder, 2004).

Elephant grass is available and abundant in almost all ecological zones in Nigeria and can be conserved for dry season feeding. Delonix regia (Caesalpinidae) wild plant otherwise called flame of the forest originated from America (Madagascar) but found wild or as ornamental plants in various parts of the world including Nigeria (Purseglove, 1994). It is an ornamental, leguminous plant, which produces tones of pods containing seed in the fruiting season (Keay et al., 1964). These seeds are left unutilized since they are neither consumed by any animal nor utilized for any other medical purposes. Seeding is abundant and germination is free. The flowers are usually red but sometimes bear a paler orange red flower and flowering is spontaneous, it is one of the most spectacular flowering trees of the tropics. It is widely grown ornamental leguminous plant, which produces $25-40 \mathrm{~cm}$ long pods containing seed which laboratory analysis has reported to contain crude protein $36.92 \%$, crude lipid $4.17 \%$, and crude fibre $11.39 \%$ (Grant et al., 1991). Report also showed that the seed extracted exhibited low haemagglutinin activity and contains nontoxic lectins. Flamboyant seed meal compared favourably with mechanically extracted groundnut cake meal in term of crude protein content (NRC, 1993). Heat treatment is employed to dry certain plant product and to improve quality of pelletized feed. Hence, heat treatment can improve the nutritional value of Delonix regia seed by reducing the anti-nutritional factors. The nutritive value of ruminant feed is determined by the concentration of its chemical component as well as rate and extent of digestion. In vitro gas methods used in estimating the digestibility and metabolisable energy (ME) of ruminant feeds (Menke and Steingass, 1988) measures digestion of insoluble carbohydrate based on the assumption that the amount of gas produced from a feed incubation reflects the production of short chain fatty acids (SCFA) which are the major sources of energy for ruminants. This study therefore determined the effect of processing on the nutritional value of mixture of Delonix regia seed meal and Pennisetum purpureum in terms of proximate, mineral, anti-nutritional compositions and in vitro gas production.

\section{Materials and methods}

The in vitro study was carried out at the Central Laboratory of the Department of Animal Science, University of Ibadan, Nigeria. Delonix regia pods were harvested within and outside Moor- Plantation Ibadan and the seeds were removed from the pods manually. Also, four weeks re-growth of elephant grass (Pennisetum purpureum) was obtained from existing pastures at Moor Plantation Ibadan and mixed at ratio 50:50 with Delonix regia seed meal. Delonix regia seeds and Pennisetum purpureum were divided into five treatments as follows: T1 (50\% soaked Delonix regia seeds and 50\% Pennisetum purpureum) had $1 \mathrm{~kg}$ of seeds soaked in 2 litres of water for 24 hours, drained and sundried for 3 days.T2 raw Delonix regia seeds which did not undergo any processing. T3 (roasted) had $1 \mathrm{~kg}$ of seeds roasted in dry frying pan on a hot plate at $60^{\circ} \mathrm{C}$ for 45 minutes. T4 (boiled) had $1 \mathrm{kgof}$ the seeds poured into boiling water for 40 minutes, drained and sundried for 3 days. T5 had four weeks re-growth of elephant grass chopped and air dried.

\section{Chemical analysis}

Each treatments samples (T1-T5) were 


\section{Olufayo and Falola}

ground in hammer mill separately and subjected to proximate analysis according to the standard method of AOAC, (2001)to determine the percentage Crude Protein (CP), Ether Extract (EE), Crude Fibre (CF), Moisture content, Ash content and Nitrogen Free Extract (NFE). The mineral and antinutritional contents were also analysed using the standard procedure.

\section{In Vitro Gas Production}

Rumen fluid was obtained from five Red Sokoto goats using the suction tube before the morning feed. The use of rumen liquor and buffer $\quad(9.8 \mathrm{~g} \quad \mathrm{NaHCO}+2.77 \mathrm{~g}$ $\mathrm{Na}_{2} \mathrm{HPO} 4+0.57 \mathrm{~g} \quad \mathrm{KCl}+0.47 \mathrm{~g} \quad \mathrm{NaCl}+0.12 \mathrm{~g}$ $\mathrm{MgSO} 4.7 \mathrm{H}_{2} \mathrm{O}+0.16 \mathrm{~g} /$ litre $\left.\mathrm{CaCl}_{2} \cdot \mathrm{H}_{2} \mathrm{O}\right)(1: 4$, $\mathrm{v} / \mathrm{v})$ under continuous flushing with $\mathrm{CO}_{2}$ for incubation was as reported by Stephen (2006). The gas production was measured at $3,6,9,12,15,18,21$ and 24 hour. After 24 hour post incubation, $6 \mathrm{ml}$ of $10 \mathrm{M} \mathrm{NaOH}$ solution was introduced as described by Fievez et al. (2005) to estimate methane. Metabolizable energy (ME, MJ/Kg DM) and Organic Matter Digestibility (OMD \%) were estimated as established by Menke and Steingass (1988) and short chain fatty acids (SCFA) was calculated as reported by Getachew et al. (1998) using $24 \mathrm{~h}$ post incubation. $\mathrm{ME}=2.20+0.136 \mathrm{Gv}+0.057 ? \mathrm{CP}$ +0.0029 ? $\mathrm{CF}, \mathrm{OMD}=14.88+0.889 \mathrm{Gv}$ $+0.45 \mathrm{CP}+0.651 \mathrm{XA} ; \mathrm{SCFA}=0.0239 \mathrm{Gv}-$ 0.0601, where Gv, CP, CF and XA are net gas production $(\mathrm{ml} / 200 \mathrm{mgDM})$, crude protein, crude fibre and ash of the incubated samples respectively.

\section{Statistical analysis}

Data obtained was subjected to one way analysis of variance (ANOVA) using SAS(1998). Means were compared using Duncan (1955) option of same software.

\section{Results and discussions}

Table 1 shows the proximate composition of mixture of processed Delonixregia seeds and Pennisetum purpureum at ratio 50:50. The dry matter ranged between 93.91-94.86, the highest value was observed in T1 $(94.86 \%)$ followed by T5 $(94.72 \%)$, T4 $(94.38 \%)$, T2 $(94.09 \%)$ and the least was T3 (93.91\%). Crude fibre ranged from 20.10-21.40\% among the treatment with $\mathrm{T} 2$ recording the highest value $(21.40 \%)$, T5 $(21.20 \%)$ observed in this experiment were similar to $22.00 \%$ reported by Bake et al.(2013). High level of crude fibre has been acknowledged by Odedire and Babayemi (2007) to be inversely related to feed digestibility and nutrient availability. Crude protein ranged from $13.38 \%-15.71 \%$ with T4 (15.71\%) recording the highest value and least value recorded in T2 (13.38\%). 13.98\% obtained for Pennisetum purpureum was higher than $8.60 \%$ reported by Ajayi (2007). This could be as a result of age since samples used for this experiment were harvested at 4 weeks of regrowth. Grasses get lignified with age which has been shown to reduce their digestibility (Duke,1983).Ash content ranged between $7.77 \%-12.34 \%$, the highest value observed in T5 (12.34\%) and lowest value was T3 (7.77\%).

Table 1: Proximate composition (\%) of processed Delonix regia seed and Pennisetum purpureum mixture at 50:50

\begin{tabular}{llllll}
\hline Parameters & T1(soaked) & T2(raw) & T3(roasted) & T4(boiled) & T5(P.purpureum) \\
Dry matter & 94.86 & 94.09 & 93.91 & 94.38 & 94.72 \\
Crude fibre & 20.40 & 21.40 & 20.29 & 20.10 & 21.20 \\
Crude protein & 14.01 & 13.38 & 13.76 & 15.71 & 13.98 \\
Ash & 7.87 & 7.93 & 7.77 & 8.09 & 12.34 \\
Ether extract & 2.38 & 3.12 & 2.11 & 2.83 & 1.90 \\
Nitrogen Free & 55.34 & 54.17 & 56.07 & 53.27 & 50.58 \\
Extract & & & & \\
\hline
\end{tabular}




\section{Processed Delonix regia seeds incubated in vitro with Pennisetum purpureum}

Table 2 showed the in vitro gas production parameters of mixture of processed Delonix regia seeds and Pennisetum purpureum at ratio 50:50. The metabolizable energy (ME) ranged between 4.75-6.85 as highest values of metabolizable energy was observed in T1 (6.85) and the least was in T5 (4.75). The values of $\mathrm{ME}$ obtained among treatments were significant. The Organic Matter Digestibility ranged from $40.16-51.49 \%$ with T5 (40.16) having the least value and T1 (51.49) had the highest value. Short chain fatty acid ranged between 0.23-0.62, methane $(\mathrm{ml} 200 \mathrm{mg} / \mathrm{DM})$ production in this study ranged between 5.00-14.00, the highest value was obtained in T3 (14.00) followed by
T2 (12.50) and the least value was in T5 (5.00). There were significant differences $(p<0.05)$ among the treatments. Highest value of $\mathrm{ME}(6.85 \mathrm{Mj} / \mathrm{kg} \mathrm{DM}), \mathrm{OMD}$ $(51.49 \%)$ and SCFA $(0.62 \mathrm{~mol})$ are consistently observed in T1 $(50 \%$ soaked Delonix regia and 50\%Pennisetum purpureum). This showed that mixture of soaked Delonix regia seeds and Pennisetum purpureum could have the highest potential to make energy available to ruminant. This observation correlates with the report of Ajayi (2007) that higher short chain fatty acid (SCFA) or volatile fatty acid (VFA) such as butyrate and acetate suggests a potential to make energy available to ruminants.

Table 2: In vitro gas production $(\mathrm{ml} / 200 \mathrm{mg} / \mathrm{DM})$ parameters of processed Delonix regia seeds incubated with Pennisetum purpureum

\begin{tabular}{lllllll}
\hline Parameters & T1 & T2 & T3 & T4 & T5 & SEM \\
\hline ME $(\mathrm{Mj} / \mathrm{kg} / \mathrm{DM})$ & $6.85^{\mathrm{a}}$ & $5.47^{\mathrm{bc}}$ & $5.49^{\mathrm{bc}}$ & $6.24^{\mathrm{b}}$ & $4.75^{\mathrm{c}}$ & 2.10 \\
$\mathrm{SCFA}(\mu \mathrm{mol})$ & $0.62^{\mathrm{a}}$ & $0.37^{\mathrm{bc}}$ & $0.37^{\mathrm{bc}}$ & $0.48^{\mathrm{b}}$ & $0.23^{\mathrm{c}}$ & 0.39 \\
$\mathrm{OMD}(\%)$ & $51.49^{\mathrm{a}}$ & $42.06^{\mathrm{bc}}$ & $42.13^{\mathrm{bc}}$ & $47.36^{\mathrm{b}}$ & $40.16^{\mathrm{c}}$ & 0.33 \\
$\mathrm{CH}_{4}(\mathrm{ml})$ & $10.00^{\mathrm{bc}}$ & $12.50^{\mathrm{b}}$ & $14.00^{\mathrm{a}}$ & $11.00^{\mathrm{bc}}$ & $5.00^{\mathrm{c}}$ & 0.50 \\
\hline
\end{tabular}

$+\mathrm{SEM}=$ standard error of mean, ${ }^{\mathrm{a}, \mathrm{b}, \mathrm{c}}$ mean on the same row with different superscript are significantly different $(\mathrm{p}<0.05)$

Table 3 showed the soluble 'a' fraction of the sample which ranged from 3.70-8.33, the value for the absolute 'a' used ideally reflects the fermentation of the soluble fraction; the extent of gas production ' $b$ ' and ' $a+b$ '

described the fermentation of the insoluble but degradable fraction of the sample. The values obtained in this study ranged between 8.63-20.00 and 12.33-28.33 respectively.

Table 3: In vitrog as production characteristic $\mathrm{s}(\mathrm{ml} / 200 \mathrm{mg})$ of processed Delonix regia seeds incubated with Pennisetum purpureum

\begin{tabular}{lllllll}
\hline Parameters & T1 & T2 & T3 & T4 & T5 & SEM \\
\hline A & $8.33^{\mathrm{a}}$ & $6.30^{\mathrm{b}}$ & $4.00^{\mathrm{bc}}$ & $8.30^{\mathrm{ba}}$ & $3.70^{\mathrm{c}}$ & 0.33 \\
$\mathrm{~B}$ & $20.00^{\mathrm{a}}$ & $11.70^{\mathrm{bc}}$ & $14.00^{\mathrm{b}}$ & $14.36^{\mathrm{ab}}$ & $8.63^{\mathrm{c}}$ & 0.37 \\
$\mathrm{a}+\mathrm{b}$ & $28.33^{\mathrm{a}}$ & $18.00^{\mathrm{bc}}$ & $18.00^{\mathrm{bc}}$ & $22.66^{\mathrm{b}}$ & $12.33^{\mathrm{c}}$ & 0.16 \\
\hline
\end{tabular}

$a=$ intercept (gas produced from the soluble fraction). $b=$ gas production from the insoluble fraction. $a+b=$ potential extent of gas production. SEM= Standard error of mean. ${ }^{\text {abc }}$ mean on the same row with different superscript are significantly different $(\mathbf{p}<0.05)$. $\mathrm{T} 1=\mathbf{5 0} \%$ soaked Delonix regia and $\mathbf{5 0} \%$ Pennisetum purpureum, $\mathbf{T} \mathbf{2}=\mathbf{5 0} \%$ raw Delonix regia and $\mathbf{5 0} \%$ Pennisetum purpureum, $\mathrm{T} 3=\mathbf{5 0} \%$ roasted Delonix regia and $\mathbf{5 0} \%$ Pennisetum purpureum, $\mathbf{T} 4 \mathbf{5 0} \%$ boiled Delonix regia and $\mathbf{5 0} \%$ Pennisetum purpureum, T5 $=100 \%$ Pennisetum purpureum.

Table 4 shows the mineral content of the raw and the processed seeds. The values obtained for calcium, phosphorus, sodium and potassium declined with processing. Mineral decline with age has been reported in tropical grasses (McDonald et al., 1995; Babayemi et al., 2006).

The values obtained for Calcium (2.34$3.61 \%)$ in this study were higher than the range $(0.40-1.5 \%)$ recommended for goats 


\section{Olufayo and Falola}

and $1.6 \%$ recommended for lactating goats (NRC, 1981). The values (0.88-1.12\%) obtained for Phosphorus were above minimum range of $0.15 \%$ recommended for ruminant (NRC, 1981). Sodium Na content ranged from $2.05-2.91 \%$ and was within the recommended requirement for ruminants (NRC, 1981). Values (2.90-3.48\%) obtained for Magnesium $\mathrm{Mg}$ was above the $0.80 \%$ recommended for lactating goats and $0.50 \%$ recommended for maintenance and nonlactating goats (NRC, 1981). It was observed generally that the 2 recorded the highest values among the treatments while the values obtained for the heat treated seeds were lower than the raw Delonix regia seed,this signified that heating had reducing effects on the mineral contents.

Table 4: Mineral contents ( $\mathrm{g} / 100 \mathrm{~g})$ of processed mixture at 50:50

\begin{tabular}{llllllll}
\hline Treatments & T1 & T2 & & T3 & T4 & T5 & \pm sem \\
\hline Calcium & $3.58^{\mathrm{b}}$ & $3.61^{\mathrm{a}}$ & $3.28^{\mathrm{bc}}$ & $3.33^{\mathrm{bc}}$ & $2.34^{\mathrm{c}}$ & 0.84 \\
Magnesium & $3.35^{\mathrm{b}}$ & $3.48^{\mathrm{a}}$ & $3.25^{\mathrm{c}}$ & $3.32^{\mathrm{b}}$ & $2.90^{\mathrm{c}}$ & 1.02 \\
Sodium & $2.28^{\mathrm{b}}$ & $2.91^{\mathrm{a}}$ & $2.12^{\mathrm{bc}}$ & $2.05^{\mathrm{c}}$ & $2.06^{\mathrm{c}}$ & 0.37 \\
Phosphorus & $0.95^{\mathrm{bc}}$ & $1.12^{\mathrm{a}}$ & $0.88^{\mathrm{c}}$ & $0.92^{\mathrm{bc}}$ & $1.09^{\mathrm{b}}$ & 0.24 \\
\hline SEM
\end{tabular}

SEM=standard errors of mean, a,b,c mean same superscript on the same row are not significantly different (p $>0.05)$.

The concentrations of some of the antinutrients were given in Table 5. Oxalates ranged between 0.23 to $0.32 \%$, phytates from 0.29 to $0.43 \%$, tannin from 0.03 to $0.08 \%$ and saponnin from 0.36 -to $0.49 \%$ ). T2 recorded the highest values among the treatments. Francis et al. (2001) reported that heat treatment substantially reduces and inactivates levels of secondary compounds in the seed. Results obtained in this present study tend to agree with their report. All the anti-nutritive factors parameters measured were lower in the treated seeds compared to $\mathrm{T} 2$.

The concentrations were decreasing with processing, the levels of saponnins were lower than values $(0.85 \%)$ reported for Pennisetum purpureum (Okaraonye and Ikewuchi, 2009) and higher than values reported for Panicum maximum (Ajayi, 2007). Saponnins reduce intake of the feed, and uptake of certain nutrients including glucose and cholesterol. From the level obtained in this study it is not likely that the saponnin content of mixture of processed Deloni xregia and Pennisetum purpureum will affect its nutritional potentials to any significant extent. The levels of tannins reported here were lower than values (28.64\%) reported for Pennisetum purpureum (Okaraonye and Ikewuchi, 2009) and Panicum maximum (Ajayi, 2007). The level of tannin which adversely affect digestibility in sheep and cattle is between $2 \%$ and $5 \%$ (Diagayete and Huss, 1981). Goats are known to have threshold capacity of about $9 \%$ for dietary tannin (Natis and Malachek, 1981). The levels of oxalates observed here ranged from $0.23 \mathrm{mg} / 100 \mathrm{~g}$ to $0.32 \mathrm{mg} / 100 \mathrm{~g}$ and it is unlikely to pose toxicity problems, since it is below $2-5 \mathrm{~g}$ reported by Oke (1969) as toxic. Oxalate affects Calcium and Magnesium metabolism (Onwuka,1983) but ruminants can consume considerable amounts of high oxalate plants without adverse effects principally due to microbial decomposition in the rumen (Oke,1969). The phytate levels observed were higher than $0.16 \%$ reported for Pennisetum purpureum by (Okaraonye and Ikewuchi, 2009). The knowledge of the phytate level in feeds is necessary because high concentration can cause adverse effects on the digestibility of minerals (Nwokolo and Bragg, 1977). Phytate forms stable complexes with $\mathrm{Cu}^{2+}$, $\mathrm{Zn}^{2+}, \mathrm{Co}^{2+}, \mathrm{Mn}^{2+}, \mathrm{Fe}^{2+}$ and $\mathrm{Ca}^{2+}$. 


\section{Processed Delonix regia seeds incubated in vitro with Pennisetum purpureum}

Table 5: Anti-nutritional contents (g/100g) of processed Delonix regia seeds and Pennisetum purpureum mixture at 50:50

\begin{tabular}{lllllll}
\hline Treatments & T1 & T2 & T3 & T4 & T5 & SEM \\
\hline Oxalate & $0.26^{\mathrm{b}}$ & $0.32^{\mathrm{a}}$ & $0.26^{\mathrm{b}}$ & $0.26^{\mathrm{b}}$ & $0.23^{\mathrm{c}}$ & 0.03 \\
Phytate & $0.38^{\mathrm{b}}$ & $0.43^{\mathrm{a}}$ & $0.34^{\mathrm{bc}}$ & $0.38^{\mathrm{b}}$ & $0.29^{\mathrm{c}}$ & 0.03 \\
Tannin & $0.05^{\mathrm{b}}$ & $0.08^{\mathrm{a}}$ & $0.04^{\mathrm{b}}$ & $0.03^{\mathrm{c}}$ & $0.04^{\mathrm{b}}$ & 0.01 \\
Saponnin & $0.36^{\mathrm{b}}$ & $0.49^{\mathrm{a}}$ & $0.38^{\mathrm{b}}$ & $0.36^{\mathrm{b}}$ & $0.37^{\mathrm{b}}$ & 0.02 \\
\hline
\end{tabular}

$\mathrm{SEM}=$ standard errors of mean, a,b,c d mean same superscript on the same row are not significantly different.p $>0.05$

Figure1 shows the rate of fermentation and the dry matter digestibility (DMD\% ) of the mixture of the processed seeds and the grass. The values obtained for the $\mathrm{DMD} \%$ ranged from 70.23 - $91.02 \%$, the soaked had the highest digestibility and rate. It was observed that the rate is directly proportional to the dry matter digestibility.

The rate of gas production 'c' ranged from
0.51-1.18. Babayemiet al.,(2004)reported that factors that determine the rate of gas production during fermentation depends on the nature and level of fibre, the presence of secondary metabolites and potency of rumen liquor for incubation; the mixture of Delonixregia seeds and Pennisetum purpureum will be higher than that of $100 \%$ Pennisetum purpureum grass in gas production.

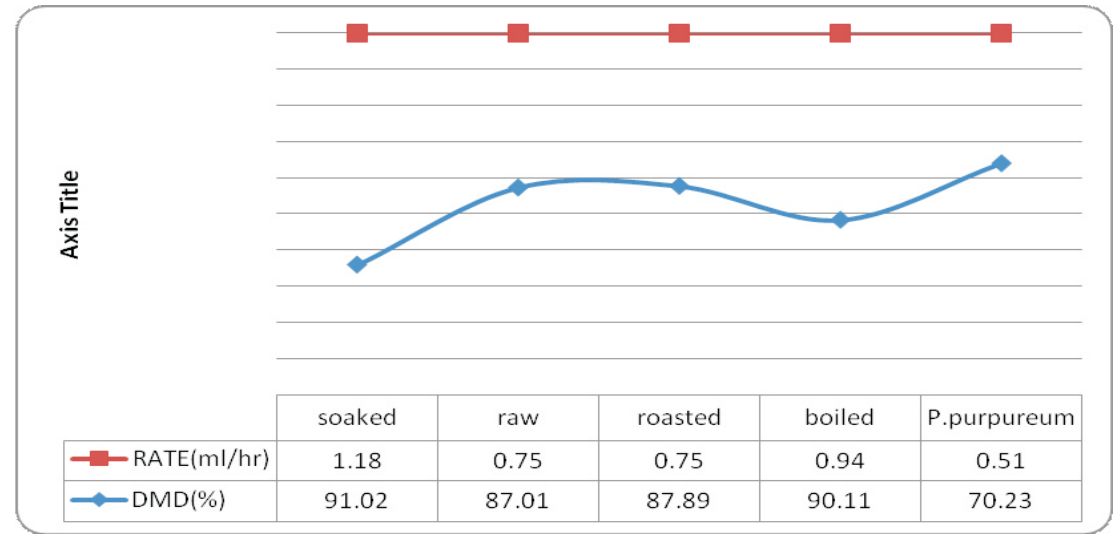

Figure 1: Rate of fermentation and dry matter digestibility (DMD\%) of the mixture of pr ocessed Delonixregia seeds with Pennisetum purpureum

\section{Conclusion}

The processing of Delonixregia seeds improved the nutritional composition by increasing the crude protein, reducing the fibre and anti-nutritional contents of the seeds. The rate of fermentation and dry matter digestibility were also enhanced by the processing techniques, most especially the soaked. Delonixregia seeds with Pennisetum purpureum can be processed and use as supplement in livestock feed.

\section{References}

Ajayi, F. T. 2007. Nutritional evaluation of Panicum maximum intercropped with some legumesfor West African Dwarf goats. Ph.D. Thesis University of Ibadan, Ibadan, Nigeria. Animal feed science and technology 123 124; 197-210.

AOAC. 2001. Official method of analysis.Association of official analytical chemist $17^{\text {th }}$ ed.Arington, VA, USA.Press, Washington,DC, 


\section{Olufayo and Falola}

$128 \mathrm{p}$.

Babayemi, O. J., Demeyer, D. and Flevez, V. 2004. In vitro rumen fermentation of tropical browse seeds in relation to their contents of secondary metabolites. Journal of Animal feed science and technology.

Babayemi O.J, Ajayi F.T, Taiwo, A.A, Bamikole, M. A and Fajimi, A.K.2006. Performance of West African dwarf goat fed Panicum maximum and concentrate diet

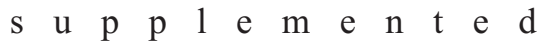
with L a blabpurpureus, LeucaenaleucocephalaandGliricidi asepiumfoliage Nigeria journal of animal production 29: 199-206.

Diagayette, M. and Huss, W. 1981. Tannin contents of African pasture plants. Effects on analytical data and invitro digestibility. Animal Research and Development $15 ; 79-90$

Duke, J. A. 1983. Ecosystematic data on Economic plants.Quart.J crude Drug Residence pg 208.

Duncan, D. B. 1955. Multiple range and multiple F-test, Biometics, 11:1-42.

Fievez, V., Babayemi, O. J. and Demeyer, D. 2005. Estimation of direct and indirect gas production in syringes, a tool to estimate short chain fatty acids production requiring minimal laboratory facilities.Animal feed science and technology. 123-124: 197-210.

Francis, G., Makkar, H. P. S. and Becker, K. 2001. Anti-nutritional factors present inplant-derived alternate fish feed ingredients and their effects in fish Aquaculture, 199, 197-198.

Getachew, G. W., Blummel, H. P., Makkar, S. and Beckerel, K. 1998. In vitro gas measuring techniques for assessment of nutritional quality of feeds; A review: Animal feeds science and technology, 72; 261281.
Glencross, B. D., Booth, M. and Allan, G. L. 2007. A feed is onlyas good as its ingredients - A review of ingredientevaluation strategies for a q u a c u l t u re fe e d s . Aquac.Nutr.,13,17-34.

Gomide, J. A. 1978. Mineral composition of grasses and tropical leguminous forages, In Latin American symposiumon mineral nutrition research with grazing ruminants Gainseville, University of Florida, pp 3240.

Grant, G., More, L. J., McKenzie, N. H., Stewart, J. C., Telek, L. and Pusztai, A. 1996. A survey of the nutritional and haemagglutination properties of legume seeds generally available. Livestock Res. Rural Dev. 1991;3:1-10.10.

Keay, P. W., Onochie, C. P., Stanfield, D. P. 1964. Nigeria trees, Federal Dept. of forestryresearch Ibadan, Nigeria. 1964;1.

McDonald, P., Edward, R. A., and Greenhalgh, J. F. D. 1995. Animal nutrition, $5^{\text {th }}$ edition, Longman Scientific and Technical, England.

Menke, K. H. and Steingass, H. 1988. Estimation of the energetic feed value from chemical analysis and in vitro gas production using rumen fluid.Anim. Res. Dev. 28: 7-55.

NRC, 1981. Nutrients requirement of goat; Angora dairy and meat goat in temperate and tropical continent.Nutrient requirement of Domestic animals.

Natis, A.S and Malachek, J.C . 1981. Digestion and utilization of nutrients oak browse by goats.Journal of Animal Science 52; 283-288.

Nwokolo, E. N. and Bragg, B. B. 1977. Influence of phytic acid and crude fibre on the availability of minerals from protein supplements in growing chicks. J. Animal science, 
$57 ; 475-477$.

Odedire, J. A. and Babayemi, O. J. 2007. Preliminary study on Tephrosiacandida as forage a $1 \mathrm{t}$ e $\mathrm{r}$ a $\mathrm{t}$ i $\mathrm{v}$ e $\mathrm{t} \mathrm{o}$ Leucaenaleucocephala for ruminant nutrition in Southwest Nigeria.Livestock Research for Rural Development 19(9).

Okaraonye, C. C. and Ikewuchi, J. C. 2009. Nutritional and Antinutritional components of Pennisetum purpureum (schumach); Parkistan Journal of Nutrition 8 (1); 32-34

Oke, O. L. 1969. Oxalic acids in plants and in nutrition ; world review of Nutrition and Dietetics 10;263-303.
Onwuka, C. F, 1983. Nutritional evaluation of some Nigeria browse plants in the humid tropics. Ph.D Thesis University of Ibadan, Ibadan, Nigeria.

Purseglove, J. W. 1994. Tropical crops: Dicotyledons.Longman, London, U.K.p 122.

Schroeder, J. W. 2004. Forage Nutrition for ruminants, extension diary specialist. Macmillan Publisher Pg 45-52.

SAS, 1998. Statistical analysis system Institute, SAS/STAT User's guide statistical, SAS Institute, Cary. North Carolina, USA.

Stephen, N. 2006. Introduction to Animal Science $3^{\text {rd }}$ ed. Oxford University Press, London Pg 81-85.

Received: $15^{\text {th }}$ November, 2017

Accepted: $20^{\text {th }}$ February, 2018 